\title{
PATHOGENECITY OF TWO STRAINS OF RICE YELLOW MOTTLE VIRUS ON AROMATIC RICE CULTIVARS
}

\author{
ZL Kanyeka \\ Department of Botany, University of Dar Es Salaam, \\ P.O. Box 35060, Dar Es Salaam Tanzania. \\ Email address: zkanyeka@yahoo.com
}

\begin{abstract}
Development of rice cultivars with resistance to rice yellow mottle virus (RYMV) requires characterization of pathogenecity of existing strains against susceptible cultivars. The pathogenecity of two RYMV strains; S4 and S"New" identified in Tanzania were assessed against seven local and introduced rice genotypes including cultivars Zambia, ITA173 and TXD 88. The two virus strains showed similar effects on the rice cultivar Zambia killing all the plants at 25d after inoculation. The strains significantly reduced the plant height, panicle length, and number of tillers per pot and total dry matter of all the two cultivars. In another trial, the pathogenecity of the two strains was assessed against four aromatic rice cultivars M-69-9, Loya, Shingo ya mwali and Motisoro. The analysis of variance revealed significant differences only among cultivars for all plant parameters except for the disease severity, which showed significant statistical differences for cultivars, strains and their interactions. The strain S"New" caused more severe disease incidences on inoculated plants than S-4 strain indicating its appropriateness to use in screening for RYMV resistance due to its aggressiveness on susceptible rice genotypes.
\end{abstract}

\section{INTRODUCTION}

Rice Yellow Mottle Virus (RYMV) is the most important pest constraint of rice in Sub-Saharan Africa. The virus is endemic to the continent and causes a devastating disease on the crop. Bakker (1974) first reported the virus in 1966 in Kenya. Since then the virus has spread to most rice growing countries in the sub-continent, particularly in West Africa where the virus induces severe crop damage and yield losses (Abo et al. 1998).

In Tanzania, RYMV was not reported until mid 1980s when the disease was first observed on an introduced cultivar ITA 173 grown in farmers' fields at Mkindo rice irrigation project in Morogoro (Kanyeka et al. 1996). The virus has since then spread fast and is now found in all the major rice growing regions and in all rice ecosystems (Ali 1999, Yamamoto et al. 1995). The most severely affected rice growing regions are Mbeya (Kyela Basin and Usangu plains in Mbarali district), Morogoro (Kilombero Valley), Arusha (Ndungu Plains) including parts of Shinyanga and Mwanza regions where the virus induces severe yield losses in farmers' fields.

RYMV is a member of the genus Sobemovirus. The beetles of the family Chrysomelideae naturally transmit the virus. It is also sap transmissible under artificial conditions (Bakker 1974). Several workers have given details of the characteristic symptoms of the disease on susceptible rice cultivars (Bakker 1974, John and Thottappilly 1987, Taylor et al. 1990). These include leaf yellowing and mottling, stunting of infected plants with narrowing of emerging leaves and incomplete panicle emergence with subsequent sterile spikelets. When the infection occurs in the early stages of plant development, susceptible cultivars normally die (Bakker 1974, Kihupi et al. 2000). Field yield losses of RYMV-infected rice cultivars ranging between $10-95 \%$ have been reported in many countries in West Africa (Awoderu 1991). In Tanzania, yield losses ranging between $20-100 \%$ have been 
observed in farmers' fields in the endemic areas (Kihupi et al. 2000, Ali 2001).

The existence of different strains of RMYV with contrasting ecological, geographical distribution within a region and with different pathogenecity on susceptible cultivars has been reported (N'Guessan et al. 2001, Banwo 2002, Abubakar et al. 2003). On the bais of coat protein protein $(\mathrm{CP})$ and serological differences, four different strains of RYMV (i.e. S3, S4, S5, S"New" are now confirmed to exist in Tanzania (Banwo 2002). The S4 strain is localized in distribution while S"New" is widely distributed in Morogoro, Mbeya, and Shinyanga. In addition, the S4 strain is claimed to be less severe than the S4 strain. Without categorizing the isolates into specific and distinct strains, Ali (1999) broadly reported about the Mwanza and Morogoro strains, where by the former was restricted to Lake zones as opposed to the widely spread Morogoro strain. Recently, Abubakar et al. (2003) revealed that in Tanzania, the RYMV strains are more diverse and each strain had specific and restricted geographical range.

The virus has gained economic substantial importance in country's rice cropping systems. Existing in different strains with diverse genetic variation in pathogenecity on susceptible varieties, there is need for a more systematic research on virus for a clear understanding of its epidemiology and future strategies of breeding for resistance to the pathogen in the country. This study is part of the on-going research on the distribution, variability and characterization of the local strains, including breeding for resistance to RYMV in rice. It aimed to assess the pathogenecity of two RYMV strains S4 and $\mathrm{S}$ "New" against selected aromatic rice cultivars.

\section{MATERIALS AND METHODS \\ RYMV strains and rice cultivars}

Two experiments were conducted in the screen-house at the Department of Botany University of Dar-Es Salaam in 2001 and 2002. Rice plants infected with S-4 and S"New" strains of RYMV were collected from Kyela Basin and Kilombero Valley respectively. At the Department, the isolates of the strains were maintained in the susceptible rice cultivar "Mwarabu", which developed characteristic RYMV disease symptoms when artificially inoculated with the virus.

In the first experiment (Experiment I) the pathogenecity of the two strains were characterized using three rice cultivars; Zambia, ITA 173 and TXD 88. The cultivar Zambia is a recent introduction from either Malawi or Zambia and is widely adopted in the Southern Highlands (Musseyi 2001). ITA173 is an improved genotype from the International Institute of Tropical of Agriculture (IITA) where as TXD 88 is a locally developed and released variety in Tanzania (Kanyeka et al. 2004).

In the second experiment (Experiment II), the pathogenecity of the two strains was assessed against four aromatic rice cultivars including M-69-9, Loya, Shingo ya mwali and Motisoro. These cultivars were collected from the Agricultural Research Institute, Katrin Ifakara.

In each experiment, seedlings of each cultivar were first raised in seedbeds for three weeks before being transplanted in plastic pots of $4 \mathrm{~L}$ capacity filled with alluvial loamy soil. Four seedlings were first planted per pot and then thinned to two seedlings per pot ten days after transplanting. Both experiments I and II were arranged in a Split Plot Design with three replications. The cultivars were assigned as main plots and the sub plots were allocated to the two strains. 


\section{Preparation of inoculum and inoculation technique}

Infected leaves of the cultivar Mwarabu were used to prepare inocula of the two strains. The inoculum was prepared by macerating about $10 \mathrm{~g}$ of infected leaves in a blender containing a sterile $0.1 \mathrm{M}$ Phosphate buffer at $\mathrm{pH}$ 7.0. Clean sterilized white sand was used as an abrasive material to damage the epidermal tissues of leaves before inoculation. Inoculation of plants was done ten days after thinning. Two leaves per plant were mechanically inoculated using a simple finger rubbing method. For each test cultivar, three pots of un-inoculated plants were served as control.

Using a score scale of 1-9 (John and Thottappilly 1987), the disease severity on inoculated plants was scored two weeks after inoculation. Agronomic characteristics including plant height, numbers of tillers per plot and panicle length were recorded at maturity. Yield losses and sterility of spikelets/panicle were not determined because monkeys damaged the plants near maturity. However, total biomass dry matter weight per pot was determined. The total plant dry weight for each pot was recorded after harvesting and the oven dried at $70^{\circ} \mathrm{C}$ for 48 hours.

\section{Statistical analysis}

The analysis of variance of the collected data was performed as described for the split plot design (Gomez and Gomez 1987). Means were separated using the Duncan Multiple Range Test (DMRT). Nevertheless, in the first experiment the analysis of variance was performed only for two cultivars because inoculated plants of the cultivar Zambia was killed by the virus at 25 days after inoculation. Percent reduction of each plant parameter caused by an infection of the two RYMV strains was also determined.

\section{RESULTS AND DISCUSSION \\ Plant characteristics}

The analyses of variance for the plant characteristics of cultivars are presented in Tables 1 and 2 for experiments I and II, respectively. There were significant differences $(\mathrm{P}<0.001)$ among cultivars for all the plant characteristics. Strains and their interactions with cultivars were not significant for the observed plant characteristics. These results indicate that the pathogenecity of the two RYMV strains were cultivar dependent and the effects of the disease on the plant height, number of tillers/plant and flag leaf length were nonstrain specific. N'Guessan et al. (2001) reported similar results on the pathogenecity of two RYMV strains S1 and S2 in West Africa. It was reported that responses of most differential cultivars were not strainspecific.

Table 1; Variance analysis of plant characteristics of cultivars inoculated with RYMV strains in experiment I

\begin{tabular}{llllllll}
\hline \multirow{2}{*}{ Source of Variation } & \multirow{2}{*}{$\mathrm{DF}$} & \multicolumn{2}{l}{ Plant height } & \multicolumn{2}{l}{ Number of tillers/pot } & \multicolumn{2}{l}{ Flag leaf length } \\
\cline { 3 - 9 } & & $\mathrm{F}^{\mathrm{z}}$ & $\mathrm{P}$ & $\mathrm{F}^{\mathrm{z}}$ & $\mathrm{P}$ & $\mathrm{F}^{\mathrm{z}}$ & $\mathrm{P}$ \\
\hline Cultivars & 3 & 27.4 & 0.001 & 19.6 & 0.001 & 4.81 & 0.001 \\
Error (a) & 6 & & & & & & \\
Strains & 1 & 0.54 & $\mathrm{NS}$ & 2.38 & $\mathrm{NS}$ & 0.83 & $\mathrm{NS}$ \\
Cultivars x Strains & 3 & 0.30 & $\mathrm{NS}$ & 0.97 & $\mathrm{NS}$ & 0.02 & $\mathrm{NS}$ \\
Error (b) & 8 & & & & & & \\
\hline
\end{tabular}

Fishers value $(\mathrm{Fz})$ and significance level $(\mathrm{P})$ of each factor, $\mathrm{P}<0.001$ indicates significant effect; NS nonsignificant effect 
Kanyeka - Pathogenecity of two strains of rice yellow mottle virus ...

Table 2: Variance analysis of plant characteristics of cultivars inoculated with RYMV strains in experiment II.

\begin{tabular}{|c|c|c|c|c|c|c|c|c|c|c|c|}
\hline \multirow[b]{2}{*}{ SV } & \multirow{2}{*}{ DF } & \multicolumn{2}{|c|}{ Plant height } & \multicolumn{2}{|c|}{$\begin{array}{c}\text { Number of } \\
\text { tillers/Pot }\end{array}$} & \multicolumn{2}{|c|}{$\begin{array}{c}\text { Panicle } \\
\text { length }\end{array}$} & \multicolumn{2}{|c|}{$\begin{array}{c}\text { Total dry } \\
\text { matter }\end{array}$} & \multicolumn{2}{|c|}{$\begin{array}{l}\text { Disease } \\
\text { severity }\end{array}$} \\
\hline & & $\mathrm{F}^{\mathrm{Z}}$ & $\mathrm{P}$ & $\mathrm{F}^{\mathrm{z}}$ & $\mathrm{P}$ & $\mathrm{F}^{\mathrm{z}}$ & $\mathrm{P}$ & $\mathrm{F}^{\mathrm{z}}$ & $\mathrm{P}$ & $\mathrm{F}^{\mathrm{z}}$ & $P$ \\
\hline Cultivars & 7 & 20.3 & 0.001 & 3.34 & 0.05 & 4.82 & 0.001 & 2.82 & 0.001 & 7.84 & 0.001 \\
\hline Error (a) & 14 & & & & & & & & & & \\
\hline Strains & 1 & 0.50 & NS & 0.17 & NS & 0.81 & NS & 2.91 & NS & 31.33 & 0.001 \\
\hline $\begin{array}{l}\text { Cultivar } \\
\text { y Strains }\end{array}$ & 7 & 0.64 & NS & 0.69 & NS & 0.34 & NS & 1.55 & NS & 3.15 & 0.05 \\
\hline Error & 16 & & & & & & & & & & \\
\hline
\end{tabular}

Fishers value $\left(\mathrm{F}^{\mathrm{z}}\right)$ and significance level $(\mathrm{P})$ of each factor, $\mathrm{P}<0.001$ indicates significant effect; NS not-significant effect.

Analysis of variance for disease infection caused by the two strains on the plants revealed significant differences among cultivars, strains $(\mathrm{p}<0.001)$ and their interactions $(\mathrm{p}<0.05$, Table 2$)$ indicating that the disease reactions caused by the two strains was cultivar and strain dependent. Similarly, N'Guessan et al. (2001) reported on the overall significant isolate $\mathrm{x}$ cultivar interactions when assessing the pathogenecity of two West African RYMV strains S1 and S2 against different indica, japonica and glaberrima cultivars.

Tables 3 and 4 show the means of plant height, flag leaf length, number of tillers per plot, panicle length and total dry matter of cultivars. In both experiments, means of plant height, flag leaf and panicle lengths of all cultivars were significantly shorter in infected plants than their un-infected counterparts. The percent reduction in plant parameters ranged from $10-70 \%$ for plant height, $42-55 \%$ for panicle length and from $5-66 \%$ for total dry matter. In Tanzania, Kihupi et al. (2000) reported that the reduction in plant height of susceptible local rice cultivars due to RYMV disease was as high as $100 \%$ and their panicles failed to emerge. Other rice workers have also reported on the negative effects of RYMV infection on yield components and agronomical characteristics in rice (N'Guessan et al. 2001, Ali 2000, Fomba 1988).

The effect of RYMV on tillering capacity of susceptible cultivars was rather inconsistent. The number of tillers per pot of infected plants was lower than the control plants only in three of the six cultivars; ITA173, TXD 88 and M-69-9 (Table 3 and 4). Results for the other three cultivars in experiment II were the opposite, whereby the number of tillers/pot of the infected plants were significantly higher $(\mathrm{P}<0.001)$ than the uninfected plants (Table 4). The increase in tillers was about $51 \%$ higher in infected over the uninfected cultivars Shingo ya mwali and Motisoro, followed by Loya (28.9\%). The results suggest that RYMV infection promoted tillering in these cultivars. This could probably be a compensatory mechanism of infected cultivars against the damaged tillers during the early infection stage. Recent study on effects of RYMV conducted at Sokoine University of Agriculture in Morogoro showed that infected plants were profusely tillering at later stages (Luzi-Kihupi 2003, Unpublished data). 
Table3: Means of plant parameters of two cultivars in experiment I

\begin{tabular}{lcccccc}
\hline & \multicolumn{2}{l}{ Infected Plant } & \multicolumn{2}{c}{ Un-Infected Plants } & & \\
Parameters & ITA 173 & TXD 88 & ITA 173 & TXD 88 & S.E. & CV (\%) \\
\hline Plant height $(\mathrm{cm})$ & $47.2 \mathrm{~b}$ & $36.5 \mathrm{~b}$ & $70.2 \mathrm{a}$ & $67.8 \mathrm{a}$ & 3.4 & 7.5 \\
Number of tillers/pot & $4.3 \mathrm{c}$ & $6.9 \mathrm{~b}$ & $12.7 \mathrm{a}$ & $13.4 \mathrm{a}$ & 2.0 & 26.2 \\
Flag leaf length $(\mathrm{cm})$ & $26.5 \mathrm{~b}$ & $17.3 \mathrm{c}$ & $29.3 \mathrm{ab}$ & $34.8 \mathrm{a}$ & 5.5 & 25.1 \\
\hline
\end{tabular}

Means followed by the same letter in a row are not significantly different $\mathrm{p}<0.05$

Table 4: $\quad$ Means of plant parameters of four cultivars in experiment II.

\begin{tabular}{lllll}
\hline \multicolumn{1}{c}{ Variety } & \multicolumn{1}{c}{$\begin{array}{c}\text { Plant height } \\
(\mathbf{c m})\end{array}$} & $\begin{array}{c}\text { Number of } \\
\text { Tillers/pot }\end{array}$ & Panicle length $\mathbf{( c m )}$ & $\begin{array}{c}\text { Total dry } \\
\text { matter }(\mathbf{g})\end{array}$ \\
Infected & & & & $7.9 \mathrm{~b}$ \\
M-69-9 & $55.0 \mathrm{~d}$ & $3.6 \mathrm{~d}$ & $11.4 \mathrm{~cd}$ & $10.8 \mathrm{~b}$ \\
Loya & $61.8 \mathrm{c}$ & $6.7 \mathrm{~b}$ & $13.4 \mathrm{c}$ & $14.8 \mathrm{a}$ \\
ARLAT 3 & $61.3 \mathrm{c}$ & $6.8 \mathrm{~b}$ & $11.0 \mathrm{~d}$ & $14.7 \mathrm{a}$ \\
Motsoro & $57.5 \mathrm{~d}$ & $8.3 \mathrm{a}$ & $10.0 \mathrm{~d}$ & $15.1 \mathrm{a}$ \\
Un-infected & & & & $16.2 \mathrm{a}$ \\
M-69-9 & $75.2 \mathrm{~b}$ & $7.0 \mathrm{~b}$ & $20.3 \mathrm{~b}$ & $14.4 \mathrm{a}$ \\
Loya & $92.3 \mathrm{a}$ & $5.3 \mathrm{c}$ & $23.0 \mathrm{a}$ & $17.3 \mathrm{a}$ \\
ARLAT 3 & $78.2 \mathrm{~b} 24.0 \mathrm{a}$ & $4.5 \mathrm{c}$ & $22.6 \mathrm{ab}$ & 3.7 \\
Motsoro & $88.2 \mathrm{a}$ & $5.4 \mathrm{c}$ & $24.0 \mathrm{a}$ & 32.2 \\
S.E. & 6.4 & 1.6 & 2.3 & 16.8 \\
CV $(\%)$ & 11.0 & 38.6 & & \\
\hline
\end{tabular}

Means followed by the same letter in a column are not significantly different at $\mathrm{p}<0.05$

Reductions in dry matter weight of infected plants were statistically lower $(\mathrm{p}<0.001)$ than the un-infected plants in all cultivars. Cultivars M-69-9 had the highest percent reduction (47.7\%), followed by Loya $(33.3 \%)$ and Shingo ya mwali had the lowest $(3.0 \%)$ (Table 4). The reduction in dry matter weight due to the RYMV infection reflects indirect negative effects of the virus on final grain yields in rice.

\section{Disease Severity}

Figure 1 shows means of disease severity in percentage caused by the two strains on four cultivars. The S4 strain caused significantly higher disease incidence on M-69-9 (60\%) and lowest on Shingo ya mwali. The S"New" strain affected the three cultivars more equally (50-54.5\%), but caused less disease in M-69-9. Banwo (2002) also reported similar results for S-4 strain being less aggressive than S"New" strain on susceptible cultivars. Although significantly different from the control, the cultivar Shingo ya mwali was the least affected cultivar by the virus than the rest of the genotypes (Fig.1). This is also reflected in the percent reduction of its plant characteristics, which were lowest of all cultivars, implying that the cultivars were the least affected by the pathogen. Farmers in growing the cultivar Shingo ya mwali in areas where the virus is endemic may be recommended along with other integrated disease management strategies to reduce the risk of the virus on the rice crop. 


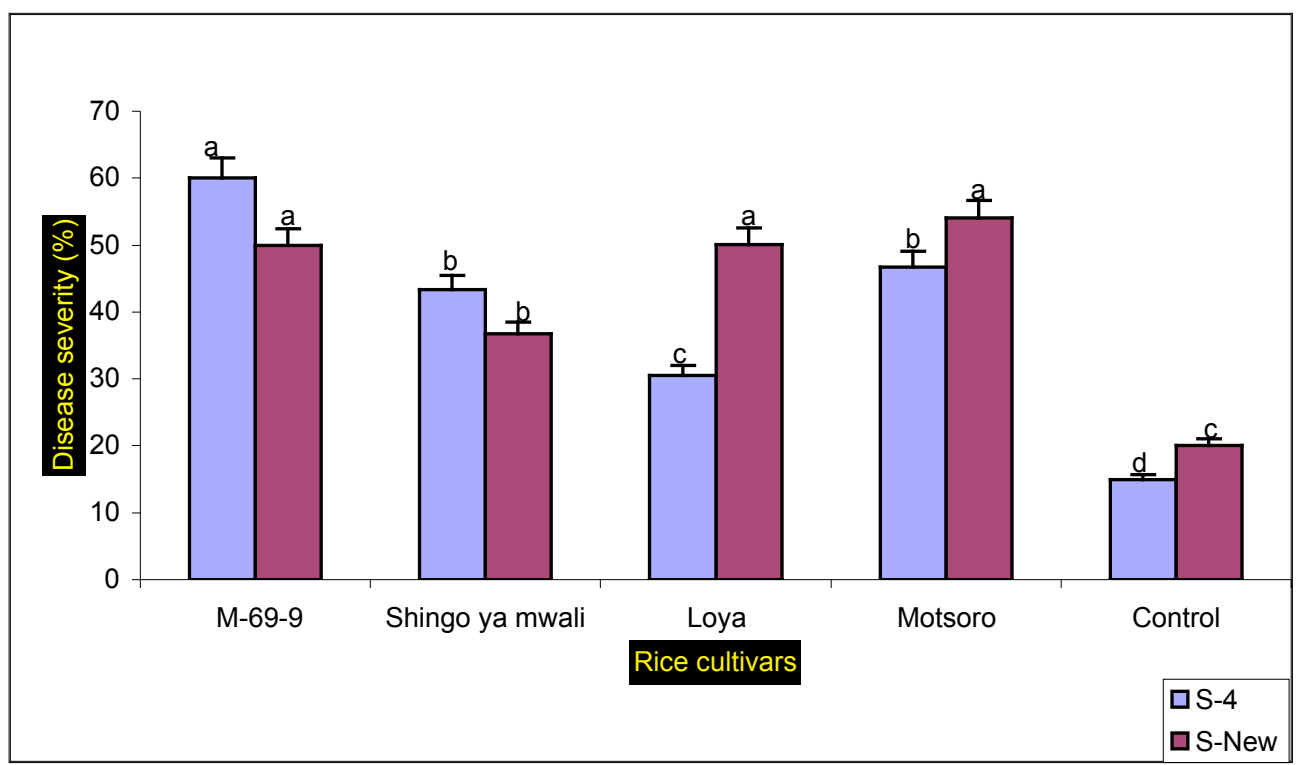

Figure 1: Disease severity infected by the two strains on of cultivars

\section{CONCLUSION AND \\ RECOMMENDATIONS}

Results obtained in this study show that the strain S-new is more aggressive than S4 on the susceptible rice cultivars. This strain could be a better choice to use in the screening rice genotypes for resistance to the virus because it can artificially create high disease pressure, an aspect more appropriate for discriminating the resistant and susceptible genotypes in breeding programs.

Among the rice cultivars assessed, the traditional aromatic cultivars; Shingo ya mwali and Loya are the least affected by the two strains. Farmers in areas endemic to RYMV can be advised to cultivate the these two cultivars to reduce he risk of the disease on the rice crops. Growing these cultivars under integrated disease management strategies can further reduce this risk of the virus and increase riceyield.

Because of the complexity of the RYMV, further systematic research on the virus should be encouraged to clearly understand its prevalence factors.
In addition, caution should be taken against introduction and rapid promotion of new high yielding rice cultivars such as Zambia without adequately knowing their reaction to the virus. This may further create conditions favorable for fast spreading of the pathogen in the country's rice cropping systems.

\section{ACKNOWLEDGEMENTS}

This work forms part of the on-going research on Genetic Improvement of the Tanzania's Local Rice Germplasm. The author is grateful to the Sida/SAREC fund facilitated through the Core Support to the Faculty of Science University of Dar Es Salaam. To Mr. B. A. Mponda for his technical assistance and to Officer In-Charge Agricultural Research Institute-KATRIN, Ifakara for provision of the rice cultivars used in this study, I am also indebted. 


\section{REFERENCES}

Abo ME. Sy AA and Alegbejo MD 1998 Rice yellow mottle virus (RYMV) in Africa: evolution, distribution, economic significance on sustainable rice production and management strategies. J.Sustain.Agricultu Research 11: 85-111.

Ali F 1999 Epidemiology of rice yellow virus in Tanzania. $\mathrm{PhD}$ Thesis, University of Greenwich. UK. 148pp.

Awoderu VA 1991 Varietal reaction to rice yellow mottle virus in upland rice ecology in Cote d'Ivoire, Nigerian Journal of Botany 4: 181-187.

Bakker W 1974 Characterization of and ecological aspects of rice yellow mottle virus in Kenya. Agricultural Research Report 829. Wageningen. The Netherlands Publishing and Documentation pp.152.

Banwo OO 2002 Vector identity, bionomics and molecular characterization of rice yellow mottle virus in Tanzania Ph.D Thesis, Sokoine University of Agriculture, Tanzania.

John VT and Thottappily G 1987 A scoring system for rice yellow mottle virus disease. Inter. Rice Res. Newsletter 12: $3-26$

Fomba SN 1988 Screening for seedling resistance to rice yellow mottle virus in some rice cultivars in Sierra Leone. Plant diseases 72: 641-642.

Kanyeka ZL, Kibanda JN and Mbapila J 1996 Rice yellow mottle virus disease in Tanzania. Paper presented at the seminar on potential and constraints for improvement of rice cultivation in
Tanzania, held on 11-15 March 1996, at KATC, Moshi, Tanzania.

Kihupi-Luzi A, Mgoo SO, Bernando VR, Mbagala RB, Mlozi MR, MsolaNchimbi $\mathrm{S}$ and Mushobozi DMK 2000 Screening for resistance to $R Y M V$ in local rice germplasm in Tanzania. Paper presented at the First -University Conference. 5-7 April 2000. Sokoine University of Agriculture, Morogoro. Tanzania.

Kihupi-Luzi A 2002 Status of variety resistance to $R Y M V$ in Tanzania. Improvement of rice production in eastern and southern Africa through research. Proc. of a Workshop on Rice in Kenya, Malawi, Zambia and Tanzania, held at KATC Moshi March 12-16, 2001.

Musseyi AN 2001 Adoption constraints of improved rice varieties in Kyela District Southern Highlands, Tanzania. Tanzania Agricultural Research and Training Newsletter. XVI: No. 1-4. pp10-12.

N'Guessan P, Pinel A, Caruana ML, Foutas R, Sy A, Chesguire A and Fargette D 2001 Evidence of the presence of two genotypes of RYMV Sobemovirus in Cote d'Ivoire. Eur.J.Plant Path. 106: 167-178.

Taylor DR, Fofie AS and Suma M 1990 Natural infection of rice yellow mottle virus disease on rice in Sierra Leone. Inter. Rice Res. Newsl. 15: 519

Yamamoto T, Pyuza AG, Lusewa RC, Harrison M and Tomitaka M 1995 Rice diseases in some parts of Tanzania. KATC Newsletter 1 (I): 4. 